
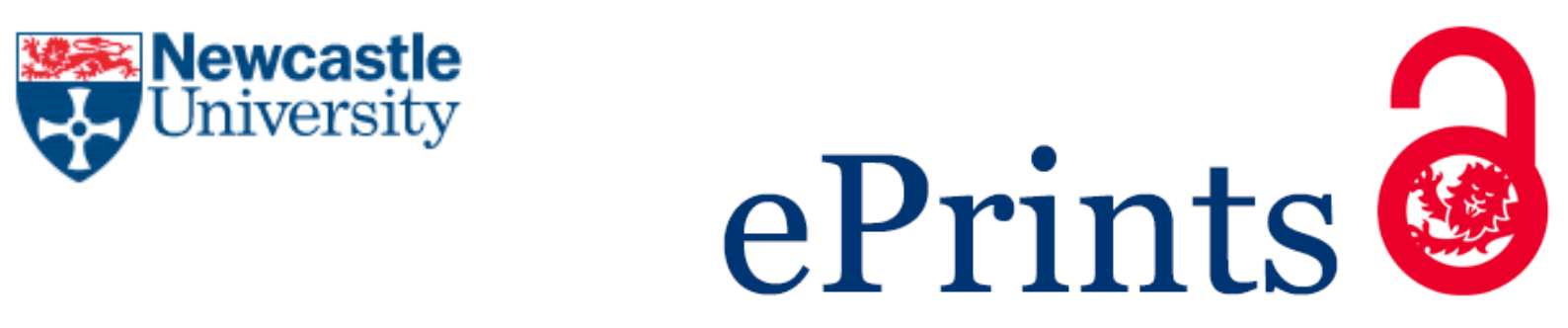

Poole, G. (2016)

Focus and the Syntacticization of Discourse.

In: Ernestina Carrilho, Alexandra Fiéis, Maria Lobo and Sandra Pereira (eds.) Romance Languages and Linguistic Theory 10: Selected papers from 'Going Romance' 28, Lisbon.

Amsterdam: John Benjamins, pp.191-210.

\title{
Copyright:
}

This is the author's accepted manuscript of a chapter that will be published in its final definitive form by John Benjamins Publishing Company, 2016. It is reproduced here with the publisher's permission.

Publisher webpage:

https://www.benjamins.com/\#catalog/books/rllt.10/main

Date deposited:

$19 / 08 / 2016$ 


\section{FOCUS AND THE SYNTACTICIZATION OF DISCOURSE ${ }^{1}$}

\section{Geoffrey Poole}

Newcastle University

geoffrey.poole@ncl.ac.uk

\section{Abstract}

This paper examines two pairs of phenomena: Quantifier Fronting in Old Spanish and Modern Spanish (Mackenzie 2010; Leonetti \& Escandell Vidal 2009) and declarative verbclitic orders in Old Spanish and 'Conservative' Asturian (Fontana 1993; Fernández Rubiera 2009). While the syntax of each construction does not change diachronically, the information-structure interpretation does. The medieval constructions both exhibit wide focus, but the modern counterparts exhibit verum focus. I argue that this change is the result of a 'syntacticization of discourse', in which the syntactic mechanism for left-peripheral displacement changes from a formal EPP feature to information-structure specific syntactic features (e.g., [+focus]) as a consequence of changes to the locus of EPP and Tense features (Biberauer \& Roberts 2010; Poole 2014).

Keywords: wide focus, verum focus, EPP, Spanish, Asturian, information structure, feature inheritance

\section{Introduction}


In this paper I examine two pairs of phenomena, Quantifier Fronting in Old Spanish and Modern Spanish (e.g., Mackenzie 2010; Quer 2002; Leonetti \& Escandell Vidal 2009) and declarative verb-clitic orders (primarily V1) in Old Spanish and 'Conservative' Asturian (Fontana 1993; Fernández Rubiera 2009; 2010). The central descriptive observation of the paper is that, in each of these pairs, while the syntax is the same in the medieval period and the modern period, the information structure interpretation differs. More specifically, during both the medieval and modern periods, Quantifier Fronting and declarative verb-clitic orders involve displacement to the low left periphery. However, while the medieval constructions both exhibit wide focus, both exhibit verum or positive polarity focus in their modern versions. $^{2}$

I suggest that this changed relationship between syntax and information-structure can be explained under the assumption that Spanish underwent a 'syntacticization of discourse' (Haegeman \& Hill 2011), developing genuinely syntactic information structure features. Prior to this change, elements are syntactically displaced to the left periphery via a purely formal EPP feature, one which does not impose or require a specific information-structure interpretation for the displaced element. After the change, by contrast, elements are attracted specifically by syntactic features with an information-structure value such as [+focus].

This diachronic development had profound consequences for these constructions because the constructions crucially involve the displacement of elements which by their nature cannot be interpreted as topics or foci. It is precisely the resolution of this conflict which accounts for the changed interpretation of the later constructions. Since it cannot be the elements themselves which are focalized or topicalized, the displaced elements are reinterpreted as proxies for the focalization of another phonetically null category. I suggest that this category is $\Sigma \mathrm{P} / \mathrm{PolP}$, the projection which encodes sentence polarity, and this is the reason why the constructions are reinterpreted as expressing verum focus. 
In Sections 2 and 3, I consider Quantifier Fronting in Old Spanish and Modern Spanish. I argue, developing observations from Mackenzie (2010), that Old Spanish Quantifier Fronting involves movement to the low left periphery, within a Rizzian articulated left periphery, and that it is interpreted as wide focus. In Modern Spanish, building on Leonetti \& Escandell Vidal (2009), I suggest that Modern Spanish Quantifier Fronting also instantiates movement to the low left periphery, but that its information structure interpretation is as verum focus. In Section 4, I argue that these facts follow from a featuretypological approach to the diachrony of EPP and T features in Spanish (cf. Biberauer \& Roberts 2010). EPP and $\mathrm{T}$ features are retained in the C-domain in Old Spanish, and are the vehicle by which the left periphery is accessed. However, they become donated to $\mathrm{T}$ in Modern Spanish, necessitating the development of syntactic information-structure features as a way of 'regaining' access to the left periphery. In other words, a syntacticization of discourse takes place. Section 5 argues that this approach also explains the diachronic difference between declarative verb-clitic structures in Old Spanish and a particular modern variety of Modern Asturian, dubbed 'Conservative Asturian’ by Fernández Rubiera. (2009; 2010).

\section{Quantifier Fronting in Old Spanish}

Mackenzie (2010), in the context of a more general discussion of certain object-verb orders in Old Spanish, notes sentences such as (1) and (2), in which a direct object quantifier has been fronted to a position immediately preceding the finite verb. ${ }^{3}$ 
(1) Si ell omne algo deue; faze gelo oluidar de guisa ques tiene que mas Rico es que otros omnes.

[If a man owes something, it [wine] makes him forget it so that he holds himself to be richer than other men.]

(General Estoria IV, 13th c., Mackenzie (2010, (22)))

(2) Mas pero non fizo y quel nada ualiesse de lo que el querie.

[But he didn't do there [anything] that was of any value to him in terms of what he wanted.]

(Estoria de España II, 13th c., Mackenzie (2010, (23)))

Syntactically, Quantifier Fronting of the kind seen in (1) and (2) is in complementary distribution with other left-peripheral fronting operations. Mackenzie $(2010,392)$ notes specifically that the phenomenon is in complementary distribution with wh-movement and focus fronting. If these elements are all competing for the same position within the low left periphery), then this distribution is explained. Furthermore, a search of the Corpus del Español (Davies 2002-) finds no instances of Quantifier Fronting in the context of interpolation structures like (3):

(3) el que ha la mano uence si lo bien sopiere iogare he that has the hand win.3s if it well know.3s play.INF 'The starting player will win if he knows how to play [the game] well.' 
Under Poole's (2013) analysis of interpolation as movement to the low left periphery, this distribution too is expected, as again, by hypothesis, the interpolated element and the fronted quantifier are competing for the same position. ${ }^{4}$

From the point of view of information structure, Quantifier Fronting in Old Spanish appears to instantiate wide focus. Prior to any consideration of context, the fronted quantifiers in (1) and (2) seem unlikely candidates for either a topical or focal interpretation. Mackenzie (2011: 392), for example, observes that quantified arguments "cannot be the domain of focus (i.e., new information focus)" because they are not, strictly speaking, licit answers to wh-questions. (They either restate or deny the presupposition of the question, rather than providing a value for a wh-operator.) Neither can (1) or (2) be instances of verum focus (as in Modern Spanish - see below). Following Leonetti \& Escandell Vidal (2009), I assume that the complement of a factive predicate is an environment which is incompatible with verum focus (because factive predicates presuppose their complements, making verum focus unnecessary/redundant). However, Quantifier Fronting can be found in these environments in Old Spanish.

(4) y así atinaron a pedir el bien y desearlo con grandes ansias and thus aimed.3P to ask.INF the good and desire.it with grand will viendo que nada podían.

see.GER that nothing could do.3P

'And thus they settled for praying for good and for desiring it with all their hearts, seeing that they could do nothing else.'

(Sermones, early $16^{\text {th }}$ c.)

(5) No seáis tan supersticioso; sé que algo ha Dios de 
NEG be.SUBJ.2P so superstitious: know.1s that something has God of perdonar.

pardon.INF

'Don't be so superstitious: I know that there's something for God to forgive.'

(Diálogo de las cosas acaecidas en Roma, early $16^{\text {th }} \mathrm{c}$.)

Furthermore, in the same way that quantifiers cannot be focalized, they cannot serve as topics either. In (1) above, for example, non-specific algo 'something' simply cannot be 'what the sentence is about'. One of the only options which is not a priori excluded is wide or broad focus - an interpretation in which no particular element is in focus. On such an interpretation, the sentence is a 'topicless neutral description' (Kuno 1972; see also Vallduví \& Engdahl (1996))..$^{5}$

This process of elimination is confirmed when we turn to contextual considerations. An examination of the wider context of these constructions suggests that Quantifier Fronting does indeed instantiate wide focus during the medieval period.

(6) E aquel que le seguiere non andara en tenjebla mas avra luz \& vida perdurable / muchas Razones dixo ihesu xpisto al pueblo delos judios quando andaua predicando entrellos porles de mostrar la carrera dela verdat [...]

[And he that follows him will not walk in darkness but will have light and everlasting life. Many words did Jesus Christ say to the people of the Jews when he went among them preaching to show them the path of truth]

(Mackenzie 2010, (56)) 
As Mackenzie (2010: 390) notes, "[h]owever hard one looks at examples like these..., it is impossible to see anything other than neutral assertions". For this reason, Mackenzie (2010) concludes that Quantifier Fronting in Old Spanish instantiates wide or broad focus. ${ }^{6}$

\section{Quantifier Fronting in Modern Spanish}

Leonetti \& Escandell Vidal (2009) consider examples such as (7) and (8) in Modern Spanish, examples which bear at least an initial similarity to the examples considered by Mackenzie in the previous section: ${ }^{7}$

(7) Nada tengo que añadir a lo que ya dije en su día. nothing have.prs.1sg to add to it that already say.pst.1sg in its day 'I have nothing to add to what I said at the time.'

(Leonetti \& Escandell-Vidal (2009, (11a)), Modern Spanish)

(8) Algo debe saber.

something must.prs.3sg know

'S/he must know something.'

(Leonetti \& Escandell-Vidal (2009, (3b)), Modern Spanish)

The modern examples in (7) and (8) appear to have an identical syntax to the medieval examples in (1) and (2). However, their information-structure interpretation differs.

Syntactically, Quer (2002, Section 3) makes a number of observations concerning Modern Spanish Quantifier Fronting. He notes that it is in complementary distribution with 
both focus fronting and wh-movement, just as the previous section observed for the medieval examples. It also appears to the right of Clitic Left-Dislocated constituents: ${ }^{8}$

(9) a. Al hospital, algo le debe donar.

To.the hospital something cl ought.3s give.inf

'He/One ought to donate something to the hospital

b. *Algo al hospital le debe donar.

(Modern Spanish)

Quer concludes (p. 263-4) on the basis of this (and other) data that Quantifier Fronting targets a position in the CP-domain of the clause. This syntactic identity strongly suggests that Quantifier Fronting in Modern Spanish is diachronically related to the Old Spanish construction (a possibility also suggested in passing by Mackenzie (2010: 394)).

However, the information structure value of the construction differs relative to its medieval counterpart. As noted by Leonetti \& Escandell Vidal, Quantifier Fronting in Modern Spanish instantiates verum focus rather than wide focus. First, with respect to the 'process of elimination', both Quer and Leonetti \& Escandell Vidal note that Modern Spanish Quantifier Fronting is incompatible with a resumptive clitic and requires that the quantifier be adjacent to the verb.

(10) Poco te $(*$ lo) puedo decir

little you.obl $(* \mathrm{cl})$ can.prs.1sg say

'I can tell you little.'

(Leonetti \& Escandell-Vidal (2009, (9c)), Modern Spanish) 
(11) Algo debe saber ella/*ella debe saber something must.3s know.inf she/she

(Leonetti \& Escandell-Vidal (2009, (11a)/(12a)), Modern Spanish)

These facts might suggest that the fronted quantifier is a contrastive focus rather than a Clitic Left-Dislocated topic, but, as they note, this cannot be the case either. ${ }^{9}$ Emphatic stress on the fronted element is not possible, nor, as illustrated by (12), can the fronted quantifier be explicitly contrasted:

(12) Nada tengo que añadir, (*no algo).

nothing have.prs.1sg to add not something

'Nothing more can be added (*not something),'

(Leonetti \& Escandell-Vidal (2009, (16a)), Modern Spanish)

Leonetti \& Escandell Vidal do note, however, that Quantifier Fronting does have certain interpretive characteristics. It has an 'emphatic' or 'evaluative' flavour (2009: 168) and appears to be 'loaded with a specific argumentative orientation' (173), and they propose on that basis that it instantiates verum or positive polarity focus, in which the truth of the proposition is emphasized.

They provide an account (2009, Section 3) of how a verum focus interpretation arises in sentences like (10)-(12) within the framework of Alternative Semantics (Rooth 1992; Krifka 2007). Because the fronted element cannot be interpreted as either a topic or a focus, 
no information partition is created. Cross-linguistically, the failure to create an information partition normally induces a wide focus reading (cf. Erteschik-Shir (2007)'s 'altruistic movement'), but this possibility is blocked in Modern Spanish by economy/markedness considerations: Modern Spanish allows wide focus to be expressed by SVO orders. Because further fronting of the object quantifier would not then be necessary to express wide focus, this interpretive possibility is blocked when the object is fronted. However, under the assumption that the purpose of focus is to introduce alternatives, and the whole sentence is focalized, then the alternative would be its negation. Therefore, what must be in focus is the sentence polarity.

In the next section, I outline a new approach to the diachrony of the left periphery in Spanish which would account for the syntactic and information structure facts discussed in this and the previous section. As we will see, the account of the verum focus interpretation of Modern Spanish Quantifier Fronting is reminiscent of the account suggested by Leonetti \& Escandell Vidal, but is expressed and contextualized rather differently.

\section{A Syntacticization of Discourse in Spanish}

I suggest that the synchronic characteristics of Quantifier Fronting, as well as its diachronic development, can be explained by considering the properties of EPP and Tense features in the two stages of the language. In Old Spanish, EPP and Tense features were retained in the Cdomain, and the EPP feature in particular served as the syntactic mechanism by which the Cdomain is accessed. By contrast, in Modern Spanish, these features are inherited by T rather than retained, necessitating the development of a new mechanism for accessing the left 
periphery. I propose that this new mechanism involved a 'syntacticization of discourse', in which genuinely syntactic information-structure features such as [+focus], were developed.

As a starting point for the discussion, consider Salvi's (2012) descriptive generalization concerning Medieval Romance. As he notes (2012: 103), it has long been observed that there are two syntactic positions which precede the finite verb. There is a position which he refers to as $\mathrm{P}_{2}$, which immediately precedes the finite verb, and a Position dubbed $\mathrm{P}_{1}$ which precedes $\mathrm{P}_{2}$. With respect to their information-structure contributions, according to Salvi, $\mathrm{P}_{1}$ hosts only thematic material, while $\mathrm{P}_{2}$ may host either thematic material $\left(\mathrm{P}_{2 \mathrm{a}}\right)$ or focal material $\left(\mathrm{P}_{2 \mathrm{~b}}\right)$, but not both. Descriptively, this echoes the observation within the cartographic approach to the left periphery (e.g., Rizzi 1997) that there is a higher topic position which precedes a lower area containing both topical and focal projections: ${ }^{10}$

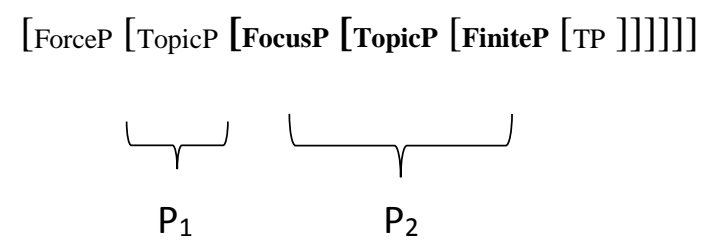

Poole (2014) confirms that Salvi's generalization is correct for Old Spanish, but argues that it should be extended in an important way: the $\mathrm{P}_{2}$ position immediately preceding the finite verb may host either thematic material, focal material, or material which is neither. As he notes, the $\mathrm{P}_{2}$ position may be occupied not only by fronted quantifiers which can be neither topical nor focal (as in e.g., (1) and (2) above), but also by interpolated elements which are semantically vacuous, as in (14), which contains a 'pleonastic' morphological negation in the complement clause of the verb negar 'to deny'

(14) podrian quebrantar las arcas \& los çilleros / \& tomar lo que quisiessen 
could.3P break.INF the chests the storehouses and take.INF it that wanted.3P

I\& despues negar que lo non tomaron.

and after deny.INF that it 'not' took.3P

'They could break into the chests and storehouses and take what they wanted and then later deny that they took it.'

(Ordenamiento de Alcalá, 14th c.)

As Poole notes, Salvi's extended generalization would be straightforwardly accounted for if the syntactic trigger for movement to the $\mathrm{P}_{2}$ position in Old Spanish were a purely formal feature such as an EPP feature. This would explain the lack of a particular information-structure requirement or interpretation with respect to the element being attracted, as well as why even semantically vacuous elements could appear. ${ }^{11}$

The presence of such an EPP feature in the low left periphery would in turn fall out naturally from an extension of Biberauer \& Roberts (2010)'s feature-inheritance typological account of Modern Romance and Germanic. Under their approach, EPP and Tense features are donated from $\mathrm{C}$ to $\mathrm{T}$ in Modern Romance, but are retained by $\mathrm{C}$ in, e.g., Modern German. Under the assumption that Old Spanish was typologically similar to Modern German, retaining the EPP and Tense features in the C-domain, the Old Spanish facts discussed in Section 2 would be expected.

Recall Old Spanish examples such as (1) above (repeated):

(1) Si [TopicP ell omne [FocusP/FinP [+EPP] algo deue... ]]

[If a man owes something....] 
Algo is attracted into the low left periphery by the EPP feature, while the subject ell omne is in the higher TopicP. From the point of view of information structure, this is a genuine instance of Erteschik-Shir 2007's 'altruistic movement'. An element such as algo is attracted by a purely formal EPP feature, but cannot itself serve as a contrastive or informational focus. Sentences such as (1) are therefore interpreted as instantiating wide focus.

However, this account of the information-structure interpretation of Quantifier Movement in Old Spanish does not extend to the Modern Spanish counterparts, such as (8) (repeated):

(8) Algo debe saber.

something must.prs.3sg know

'S/he must know something.'

(Leonetti \& Escandell-Vidal (2009, (3b)), Modern Spanish)

As Poole (2014) argues, Modern Spanish differs from Old Spanish in no longer retaining EPP and Tense features in the C-domain. Instead, the assumption is that the EPP and Tense features are donated to T, aligning with Biberauer \& Roberts' account of Modern Romance. Therefore, the mechanism by which algo is attracted into the low left periphery in (8) must be something different.

In fact, examples such as (8) represent a fully general problem, given the proposed diachronic development. If movement to the low left periphery is mediated by the EPP feature retained in the C-domain, then when that feature changes from being retained to being donated to $\mathrm{T}$, it removes the mechanism by which the left periphery of the sentence was accessed. Given the fact that elements in Modern Spanish unquestionably undergo 
displacement to the left periphery, it must be the case that another mechanism was developed in the wake of EPP-feature inheritance.

I suggest that this new mechanism involved a 'syntacticization of discourse' (the phrase is originally due to Haegeman \& Hill 2011), in which an aspect of the post-syntactic discourse/information-structure computation becomes, in a sense, grammaticalized. In Old Spanish, it is a consequence of Poole (2014)'s account that the information structure partitioning of the sentence (into, e.g., topic/comment or focus/background) takes place postsyntactically. The EPP feature in the C-domain which attracts elements to the $\mathrm{P}_{2}$ position is a purely formal feature, without any intrinsic information-structure value. In other words, elements displaced to the low left periphery are not specifically identified as topical or focal by the syntax. However, I suggest that, as part of the transition from Old Spanish to Modern Spanish, this aspect of post-syntactic information-structure became 'syntacticized', resulting in the development of 'true' syntactic features, such as [+focus]. ${ }^{12}$ Unlike a purely formal EPP feature, these features do provide interpretive instructions to the syntax/informationstructure interface, and therefore any displacement which is triggered by these features must be instances of, e.g., topicalization or focalization.

Such a development would naturally explain why the fronting of quantifiers of the sort discussed above should develop from expressing wide focus in (1) to expressing verum focus in (8). Just as in Old Spanish, the fronted quantifier in Modern Spanish cannot itself serve as a topic or as a focus. But if displacement to the low left periphery in Modern Spanish necessarily involves the checking of a feature with information-structure import, it must be that the displacement of the quantifier in fact reflects the displacement of some other phonetically null category to which the quantifier has moved. In other words, it is not the quantifier which is undergoing information-structure related displacement, but some other category. An obvious candidate for the underlying phonetically null element which is 
undergoing displacement in (8) is $\Sigma \mathrm{P} / \mathrm{PolP}$, the projection which encodes sentence polarity. It is the focalization of affirmative sentence polarity specifically which gives rise to the verum focus interpretation and its 'emphatic' or 'evaluative' flavour. ${ }^{13}$

More specifically, following Hernanz's 2006 and Batllori \& Hernanz's 2013 account of 'high' emphatic polarity particles such as sí 'yes' and bien 'well/indeed', I assume that these cases of verum focus fronting involve movement of the quantifier to the specifier of $\Sigma \mathrm{P} /$ PolP to license its null head, followed by movement to the specifier of FocusP in the low left periphery. ${ }^{14}$

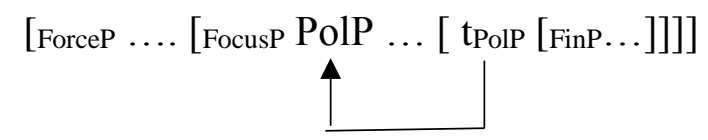

(Batllori \& Hernanz (2013: (54))

A derivation such as (15) predicts, for example, that, like emphatic sí and bien, verum focus constructions should share a number of properties with wh-operators, and these predictions appear to be verified. Verum focus fronting triggers subject-verb inversion (e.g., (11) above) and is incompatible with wh-movement or focus-movement (Leonetti \& Escandell-Vidal 2009: 167), while the fronted element must be left-adjacent to the finite verb and appears to the right of clitic left-dislocated elements (e.g., (9) above). ${ }^{15}$

Some support for the idea that syntactic focus features developed during the transition from Medieval to Modern Spanish can be found in Poole (2011)'s analysis of the diachrony of n-words in Spanish (Laka 1990). N-words are nominal and adverbial expressions such as nada 'nothing' and nadie 'no one', which are standardly translated as negative in isolation, but which produce a single logical negation in the context of sentential negation or of another n-word. Poole notes that the diachronic development of n-words suggests that a change in the syntax of focus took place during the Golden Age period $\left(16^{\text {th }}-\right.$ mid $17^{\text {th }} \mathrm{c}$. $)$ and more specifically that n-words acquire an $A^{\prime}$-related focus feature. This is reflected principally in 
their development into negative concord items from negative polarity items, following Watanabe's (2004) analysis of negative concord (in which an uninterpretable focus feature is crucially implicated). Poole also observes a diachronically parallel emergence of emphatic and contrastively fronted n-words, particularly nada. These findings would be explained if it was the syntactic focus feature itself which developed during this period. ${ }^{16}$

\section{Declarative Verb-Clitic Orders in Old Spanish and Modern Asturian}

The previous sections have focused on XP movement and changes to the EPP feature. In this section, I turn to the diachronic change of the $\mathrm{T}$ feature, the other feature in Biberauer \& Roberts' typology, by examining the development of some declarative verb-clitic orders.

Unlike Modern Spanish, the finite verb in Old Spanish could under certain circumstances precede an object or indirect object clitic in a declarative clause, as illustrated by (16)

(16) rogaronle que les diesse la llaue. Respondio les el que lo non begged.3P.him that them gave.3s the key responded them he that it not farie; would-do 'They begged him to give them the key. He replied that he would not do it.' (Old Spanish, adapted from Fontana $(1993,110)$ )

The fact that the verb precedes the object clitic suggests that the verb has raised to a relatively high position and indeed the claim of authors such as Fontana (e.g., 1993: 110) is that these 
cases involve 'V-to-C' movement. Furthermore, following Sitaridou (2012)'s analysis of Old French (though in fact contra her specific analysis of Old Spanish), the possibility for subject inversion in participial constructions (Benincà 1994) (17) and for the verb to precede high adverbs (18) are further indications that the verb raises to a high, C-related position. ${ }^{17}$

(17) \& de Caripdis. de quien auemos nos contado enla tercera parte desta estoria. And of $\mathrm{C}$ of who have.1P we related in.the third part of.that history "... and about Caripdis, about whom we have spoken in the third part of that history..."

(General Estoria IV, $13^{\text {th }}$ c.)

(18) touo verdadera mente ella con todo su entendimiento que ellos errauan Had.3s truly she with all her understanding that they erred.3P "It became clear to her that they were making a mistake...."

(Conde Lucanor, 14th c.)

The suggestion outlined in the previous section that Old Spanish is characterized by the retention of EPP and Tense features in the C-domain would provide a mechanism by which such raising could take place.

The traditional interpretive label for sentences like (16) is 'narrative inversion'. They indicate discourse cohesion or logical consequence. Intuitively, the focus is on the whole event, rather than any individual sub-part, making wide focus a logical way of characterizing this interpretation. Furthermore, such analysis would align Old Spanish with the general cross-linguistic agreement that narrative inversion/logical consequence V1 structures are wide or broad focus. ${ }^{18}$ 
While Modern Spanish no longer allows verb-clitic orders with finite verbs, Fernández Rubiera $(2009 ; 2010)$ notes that sentences such as (19) are possible in a variety of modern Asturian, a Romance variety spoken in northern Spain, which he dubs 'Conservative Asturian'.

\section{Digo [qu’ayúdame]}

Say.1s that-help.3s-me

'I say that he/she helps me out'

(Conservative Asturian, Fernández Rubiera 2010))

Verb-clitic orders are only possible after certain predicates (and in the absence of another element in the left-periphery). However, they are completely disallowed in these contexts in Modern Standard Asturian. ${ }^{19}$

Like the Old Spanish construction discussed above, cases such as (19) also appear to involve movement of the verb to the C-domain/low left periphery. As noted by Fernández Rubiera, clitics target the T-domain in Asturian. ${ }^{20}$ Therefore, the fact that the verb precedes the object clitic in (19) indicates that it has raised to a higher position than that, making the C-domain an obvious possibility. However, unlike the verb-clitic orders in Old Spanish, this order does not instantiate wide or broad focus.

More specifically, Fernández Rubiera notes that the verb-clitic order in (19) above possesses what he calls a '[+conviction]' interpretation which is absent from the corresponding sentence with clitic-verb order.

\section{Digo [que me ayuda]}

say.1s that me help.3s 
'I say that she helps me out'

(Asturian, Viejo (2008), cited in Fernández Rubiera 2010))

As Fernández Rubiera (2009: 91) characterizes it: “[(19)] attributes to the matrix predicate’s subject, who is also the speaker in this case, a pragmatic 'conviction' ensuring that the new employee truly helps him, leaving no room to think otherwise". In (20) on the other hand, the interpretation is one in which the subject "only state[s] what s/he thinks, with attributing any kind of 'conviction" (ibid.)

As Fernández Rubiera 2009 notes, the [+conviction] interpretation manifests itself in a number of ways. First, he observes that a verb-clitic order disallows certain continuations. More specifically, continuations which cast doubt on the certainty of the claim are infelicitous when the embedded clause has verb-clitic order in (19) (though perfect with the clitic-verb order in (20)).

(21) Digo qu'ayúdame...

Say.1s that-help.3s-me

...\#pero nun toi seguru/...\#anque nun toi enfotáu del too

but NEG am sure though NEG am convinced of the all

"I say that s/he helps me out...

...but I am not sure that s/he helps me/though I'm not totally convinced" (Conservative Asturian, adapted from Fernández Rubiera 2010)

Furthermore, if a yes/no question is asked literally about one's convictions, a 'yes' answer requires the verb-clitic order, while a 'no' answer requires clitic-verb. 
(22) a. ¡Oye, Xulio! Entós, ¿tas convencíu de que te ayuda?

listen Xulio so are2SG convinced of that youCL help3SG

'Listen, Xulio! So are you convinced that s/he helps you?'

b. Sí, digo qu'ayúdame /\#me ayuda

yes, say1SG that-help3SG-IND-meCL/ meCL help3SG-IND

'Indeed, I say (and I am convinced) that s/he helps me'

c. Non, digo qu' \#ayúdame /me ayuda...

no, say1SG that-help3SG-IND-meCL/meCL help3SG-IND

'No, I only say (and I am not totally sure) that s/he helps me'

(Conservative Asturian, Fernández Rubiera 2009, 92)

With respect to a more specific characterization of the [+conviction] interpretation, Fernández Rubiera (2010: 86) connects the interpretation to assertive illocutionary force due to the presence of a Force ${ }^{\mathrm{o}}$ head. However, even to the extent that embedded clauses are capable of possessing illocutionary force, it is not clear that mere assertive illocutionary force provides the strength seen in the [+conviction] interpretation.

An alternative characterization, which would account more naturally for the strength of the [+conviction] interpretation, is verum focus, the focus on the truth value of the sentence. Insofar as sentences involving verum focus can be paraphrased as it is true that... or it is the case that..., that would seem to more closely correspond with [+conviction].

Some support for the idea that the [+conviction] interpretation is verum focus can be found in observations by Quer (2002) concerning Modern Spanish Quantifier Fronting, 
which, as discussed in Section 3 above, is also a case of verum focus. Quer notes (p. 263-4) that embedded Quantifier Fronting is possible after certain predicates which are epistemic or assertive:

(23) Creo que.../Supongo que.../Me parece que...

believe.1s that suppose.1s that me.DAT seems.3s that ...algo debe saber

'I believe/I suppose/it seems to me that s/he must know something.'

(Modern Spanish, adapted from Quer $(2002,264)$ )

Crucially, these are precisely the predicates which Fernández Rubiera identifies in Conservative Asturian as licensing verb-clitic order and the [+conviction] interpretation in their complement clauses. If the [+conviction] interpretation is verum focus, then this generalization would be explained: these are predicates which allow the speaker to focus on the truth value of their complements, though Modern Spanish and Conservative Asturian have evolved different syntactic mechanisms for expressing this. ${ }^{21}$

Just as in the Modern Spanish Quantifier Raising cases discussed above, I assume that all varieties of Modern Asturian, unlike Old Spanish, mediate access to the low left periphery with syntactic features which carry an information-structure value. Therefore, when a verb is fronted to the low left periphery (an element which does not in and of itself create an information-structure partition), this is necessarily interpreted as an instance of pied-piping, occasioned by the focalization of the phonetically null category $\Sigma \mathrm{P} / \mathrm{PolP}$

\section{Conclusion}


The central descriptive observation of this paper has been that syntactic structures which exhibit wide or broad focus in Old Spanish come to exhibit verum focus in later varieties. The reason for this, I suggest, is due to changes in the syntax/information-structure interface during the history of Spanish (and related varieties) which constituted a syntacticization of discourse.

In Old Spanish, the low left periphery was accessed by an EPP/Tense feature combination which was retained in the C-domain. Such features, not being informationstructurally marked, did not themselves impose a specific information-structure interpretation on the displaced element. As a result, in cases where an 'impossible' topic or focus element was attracted, it signalled wide focus.

By contrast, in Modern Spanish and Conservative Asturian, the EPP and Tense features are no longer retained in the $\mathrm{C}$-domain, but rather are inherited by $\mathrm{T}$ (aligning with Biberauer \& Roberts' (2010) account of Modern Romance). In the wake of this event, a new mechanism for accessing the low left periphery developed in the form of informationstructure specific syntactic features, such as [+focus]. As a consequence, focalization of an 'unfocalized' element must express focalization of something, and I have suggested that it is focalization of $\Sigma \mathrm{P} / \mathrm{PolP}$. This in turn explains why the modern counterparts of these constructions should exhibit verum focus.

\section{REFERENCES}

Batllori, Monserrat \& Maria-Lluïsa Hernanz. 2013. "Emphatic Polarity Particles in Spanish and Catalan." Lingua 128, 9-30. 
Batllori, Monserrat \& Maria-Lluïsa Hernanz. 2015. "Weak Focus and Polarity: Asymmetries Between Spanish and Catalan”. In Theresa Biberauer \& George Walkden (eds.) Syntax Over Time: Lexical, Morphological and Information-Structure Interactions. Oxford: Oxford University Press, 280-298.

Batllori, Monserrat \& Maria-Lluïsa Hernanz. no date. Pre-review version of Batllori \& Hernanz 2015. Available at http://habilis.udg.edu/ info/ $\underline{\text { Activitat_Docent_Recerca_Gestio/Montserrat_Batllori/BatlloriHernanzPosterDIGS12C }}$ ambridge.pdf. [Accessed: 08/01/16]

Benincà, Paola. 1994. “Osservazioni sulla sintassi dei testi di Lio Mazor.” In Paola Benincà, ed. La variazione sintattica: studi di dialettologia romanza. Bologna: Il Mulino, 163176.

Biberauer, Theresa \& Ian Roberts 2010. "Subjects, Tense and Verb-movement." In T. Biberauer et al (eds.) Parametric Variation: Null Subjects in Minimalist Theory. Cambridge: Cambridge University Press, 263-303.

Davies, Mark. 2002-. Corpus del Español (100 million words, 1200s-1900s). Available online at http://www.corpusdelespanol.org

d'Andrés Díaz, Ramón. 1993. Allugamientu de los Pronomes Átonos col Verbu n'Asturianu. (Colección Series Minor 2). Uviéu: Departamentu de Filoloxía Española, Universidá d"Uviéu.

Erteschik-Shir, Nomi. 2007. Information Structure: The Syntax-Discourse Interface. Oxford University Press: Oxford.

Escandell-Vidal, Victoria \& Manuel Leonetti. 2011. "On the Rigidity of Procedural Meaning”. In Victoria Escandell-Vidal, Manuel Leonetti \& Aoife Ahern (eds.) Procedural Meaning: Problems and Perspectives. Bingley: Emerald Group Publishing, $81-102$ 
Fernández Rubiera, Francisco. 2006-2008. "Another Look at the [+finite] Subordinate Context in Western Iberian Romance.” Revista de Filoloxía Asturiana 6/7/8, 289-309. Fernández Rubiera, Francisco. 2009. Clitics at the Edge: Clitic Placement in Western Iberian Romance Languages, $\mathrm{PhD}$ dissertation, Georgetown University.

Fernández Rubiera, Francisco. 2010. "Force ${ }^{\mathrm{o}}$, Finiteness ${ }^{\circ}$ and the Placement of Clitics in Western Iberian Romance Languages.” Estudios de lingüística galega 2, 75-95.

Fontana, Josep M. 1993. Phrase Structure and the Syntax of Clitics in the History of Spanish. Ph.D. dissertation, University of Pennsylvania.

Haegeman, Liliane \& Virginia Hill. 2011. "The Syntacticization of Discourse." paper presented at ONLI Belfast.

Hernanz, Maria-Lluïsa. 2006. "Emphatic Polarity and C in Spanish.” In L. Brugè (ed.), Studies in Spanish Syntax. Venezia: Libreria Editrice Cafoscarina, pp. 105-150.

Hinterhölzl, Roland \& Svetlana Petrova. 2009. "From V1 to V2 in West Germanic.” Lingua 120: $315-328$.

Jasinskaja, Katja. 2014. "Information Structure in Slavic." In Caroline Féry \& Shinichiro Ishihara. Handbook of Information Structure. Oxford: Oxford University Press.

Kotcheva, Kristina et al. 2014. "A Diachronic Perspective on V1 in Icelandic." Ms. University of Konstanz.

Krifka, Manfred. 2007. "Basic Notions of Information Structure.” In Caroline Féry, Gisbert Fanselow \& Manfred Krifka (eds.) The Notions of Information Structure. Potsdam: Universitätsverlag Potsdam, 13-55.

Leonetti, Manuel \& Victoria Escandell-Vidal. 2009. "Fronting and Verum Focus in Spanish." In Andreas Dufter \& Daniel Jacob (eds). Focus and Background in Romance Languages. Amsterdam: John Benjamins, 155-204. 
Mackenzie, Ian. 2010. "Refining the V2 Hypothesis for Old Spanish.” Bulletin of Hispanic Studies 87 (4), 379-396.

Poole, Geoffrey. 2007. "Interpolation and the Left Periphery in Old Spanish.” In Miri Hussein, Marina Kolokante \& Clare Wright (eds.), Newcastle Working Papers in Linguistics 13. Newcastle upon Tyne: School of English Literature, Language \& Linguistics, Newcastle University.

Poole, Geoffrey. 2011. "Focus and the Development of N-words in Spanish". In: Janine Berns, Haike Jacobs and Tobias Scheer (eds.) Romance Languages and Linguistic Theory 2009: Selected Papers from "Going Romance" Nice 2009. Amsterdam and Philadelphia: John Benjamins, 291-304.

Poole, Geoffrey. 2013. "Interpolation, Verb-second, and the Low Left Periphery in Old Spanish”. Iberia: An International Journal of Theoretical Linguistics 5(1), 69-95.

Poole, Geoffrey. 2014. "Feature Inheritance in Old Spanish: (re)visiting V2", paper presented at the 2014 Meeting of the Linguistics Association of Great Britain, 1-5 September, Oxford University.

Quer, Josep. 2002. "Edging Quantifiers. On QP-fronting in Western Romance." In C. Beyssade, R. Bok-Bennema, F. Drijkoningen \& P. Monachesi (eds) Romance Languages and Linguistic Theory 2000 [Current Issues in Linguistics 232]. Amsterdam: John Benjamins, 253-270.

Rizzi, Luigi 1997. "The Fine Structure of the Left Periphery." In Liliane Haegeman (ed.) Elements of Grammar. Amsterdam: Kluwer Academic Publishers, 281-337.

Rooth, Mats. 1992. “A Theory of Focus Interpretation.” Natural Language Semantics 1(1): $75-116$. 
Salvi, Giampaolo. 2012. "On the Nature of the V2 System of Medieval Romance." In Laura

Brugé et al. (eds.) Functional heads: the cartography of syntactic structures, volume 7.

Oxford: Oxford University Press, 103-111.

Sitaridou, Ioanna. 2011. "Word Order and Information Structure in Old Spanish." Catalan

Journal of Linguistics 10, 159-184.

Sitaridou, Ioanna 2012. “A Comparative Study of Word Order in Old Romance.” Folia

Linguistica 46(2), 553-604.

Vallduví, Enric \& Elisabet Engdahl. 1996. "The Linguistic Realization of Information

Packaging.” Linguistics 34, 459-519.

Viejo Fernández, Xulio. 2008. Pensar asturiano. Ensayos programáticos de sintaxis

asturiana. Uviéu: Trabe.

Wilson, Deirdre \& Dan Sperber. 1993. "Linguistic Form and Relevance.” Lingua

90: $1-25$

Zagona, Karen. 2002. The Syntax of Spanish. Cambridge: Cambridge University Press.

\footnotetext{
${ }^{1}$ Thanks to Maria Maza, the audience at the 2014 Going Romance meeting and two anonymous reviewers for comments and helpful discussion. All unattributed examples from Old Spanish are taken from the Corpus del Español (Davies 2002-)

${ }^{2}$ I should note that by 'Quantifier Fronting', I restrict myself here to a relatively small set of bare (weak) quantifiers, such as algo 'something' which cannot plausibly be interpreted as either topical or focal when fronted. While other quantificational DPs undergo a superficially similar fronting, it is not entirely clear that the phenomenon is a unified one (see the remarks in, e.g., Leonetti \& Escandell-Vidal 2009: footnote 9; Batllori \& Hernanz 2015: footnote 12). A more fine-grained analysis of the information-structure effects of different fronted elements is clearly desirable (though difficult, particularly for Old Spanish). See footnotes 3 and 6 for discussion of some of the issues.

${ }^{3}$ In addition to fronted quantifiers of the sort under discussion, the other classes of fronted 'objects' that Mackenzie considers include (1) predicate adjectives and nouns, (2) pseudo-arguments (e.g., hambre 'hunger' in the predicate tener hambre 'to be hungry') and (3) resumptive elements such as esto 'this'. I put consideration of these to one side here. It is not clear that cases such as (1) and (2) have genuine counterparts in Modern Spanish, while cases such as those in (3) do not raise the specific paradox/problem regarding informationstructure interpretation which is the central point of discussion in Sections 2 and 3. This also then makes it correspondingly more difficult to establish their information-structure value of the fronting in Old Spanish (e.g., wide focus vs. (familiar) topic). See also footnotes 6 and 13.
} 
${ }^{4}$ Indeed, the complementarity of distribution can be inferred from the well-known verb-adjacency requirements on all these constructions (as noted by, e.g., Sitaridou $(2011,174)$ for new information focus and Poole (2007; 2013) for interpolation, among others). See also the discussion of Salvi's (2012) Generalization in Section 4 below.

${ }^{5}$ As noted by an anonymous reviewer, it is true that some fronted quantifiers can be focalized in Modern Spanish, while others can serve as clitic left-dislocated topics. I suspect that this is related to the informationstructure interpretation issue discussed in footnotes 2 and 6 and, as such, I leave the question for future research. ${ }^{6}$ See Mackenzie (2010) for much further discussion. One reason for suspecting that, for example, Mackenzie's 'resumptive preposing' cases discussed above in footnote 3 may be information-structurally different from the fronted quantifiers discussed here is that they appear capable of undergoing interpolation (modulo the general length constraints on interpolated elements). This is in contrast to the quantifiers under discussion here, which essentially cannot. While a search of the Corpus del Español finds over 50 instances of interpolation of esto during the $13^{\text {th }}$ and $14^{\text {th }}$ centuries (when interpolation was at its height), there are only three cases of interpolation of algo and none at all of nada during the same period. (This is not simply due to the fact that esto occurs more frequently than algo in the corpus during this period. The frequency of interpolation of esto is almost 50\% greater than its frequency of occurrence relative to algo .) Poole (2013) argues that interpolated elements act as given or familiar topics, which raises the possibility that the information structure interpretation in the 'resumptive preposing' case is subtly different from cases involving the fronting of the kind of quantifiers considered here. See also footnote 2.

${ }^{7}$ Again, echoing footnote 3 above, Leonetti \& Escandell-Vidal do consider other cases of fronted elements, some of which superficially parallel the quantifier fronting cases discussed here (particularly resumptive elements such as esto 'this'). From a technical point of view, their derivation would proceed identically to the derivation proposed in Section 3 for fronted quantifiers in Modern Spanish, if indeed they instantiate verum focus (but see the previous footnote and footnote 2). A closer examination of their diachrony is clearly warranted, but I leave it for future research.

8 (9a) is loosely adapted from Quer (2002, (12b))'s Catalan example.

${ }^{9}$ As is well-known (e.g., Zagona 2002, 217-18), left-peripheral focus in Modern Spanish can only be used for contrastive focus, not new information focus.

${ }^{10}$ I do not, however, assume a cartographic approach to the left periphery in Old Spanish for reasons which will become apparent below.

${ }^{11}$ This account of the left periphery has implications for the analysis of SVO word orders in Old Spanish, as noted by an anonymous reviewer. I leave a detailed discussion of the issues for future research. However, it would not be surprising for the EPP-feature to attract the subject in many cases as the 'nearest' DP, in which case it could naturally receive a default topical interpretation in a way that it impossible for a fronted quantifier such as algo. An alternative possibility is suggested by the work of Sheehan (2010), who connects the wide focus interpretation of SVO orders in Modern Spanish to satisfaction of the EPP-feature, now residing in the Tdomain rather than the $\mathrm{C}$-domain. (See below for further discussion of the migration of the EPP feature from the $\mathrm{C}$-domain to the T-domain.)

12 The precise explanation for this diachronic change I leave for future research, as it is beyond the scope of this chapter. One possibility, suggested indirectly by an anonymous reviewer, is that the distinction between conceptual and procedural meaning (e.g., Wilson \& Sperber 1993) could be involved. Conceptual meaning can be modified or adjusted (particularly in the context of accommodating relevance considerations), while procedural meaning ('instructions' in the sense of Escandell-Vidal and Leonetti 2011) cannot. If some aspect of this distinction were to underlie the change in the language's treatment of information-structure interpretation, it could explain why information-structure interpretation for any given left-peripherally fronted item becomes more rigid in Modern Spanish. Furthermore, Escandell-Vidal \& Leonetti (2011) propose a connection between procedural meaning and functional categories, in which case the development of functional categories as a way of expressing a newly-proceduralized approach to information-structure interpretation would be a natural result. ${ }^{13}$ Batllori \& Hernanz (2015: footnote 12) note that not all cases of what they term "weakly focus fronted" elements have this interpretation and suggest that weak focus fronting may not be a homogeneous phenomenon. I restrict myself here to those frontings which do have this interpretation. The remarks in footnotes 3 and 6 may be relevant in this context.

${ }^{14}$ From their discussion of examples (52)-(54), Batllori \& Hernanz appear to take FinP to correspond to IP within a traditional CP/IP system, rather than being the lowest projection of an expanded CP. Therefore PolP dominates FinP rather than the reverse. I take no position on this issue as I believe it has no effect on the proposed analysis.

${ }^{15}$ Batllori \& Hernanz (2015: 295-6) independently indirectly suggest a similar analysis for Modern Spanish verum focus cases, putting together their agreement that verum focus involves PolP with their general claim that 
"weak focus fronted" elements move to an unmarked Focus position in Modern Spanish (as opposed to Modern Catalan). (See also examples (45) and (49) in Batllori \& Hernanz no date.)

${ }^{16}$ See Poole (2011) for further discussion.

${ }^{17}$ Under the assumption that verdadera mente in this context is equivalent to French vraiment 'really'.

${ }^{18}$ See, e.g.. Hinterhölzl \& Petrova 2010 (West Germanic), Jasinskaya 2014 (Slavic) and Kotcheva et al. 2014 (Icelandic).

${ }^{19}$ See, e.g., d'Andrés Diaz 1993, Viejo 2008. I return to this issue below.

${ }^{20}$ I leave open whether they target specifically $\mathrm{T}^{\mathrm{o}}$ itself (Fernández Rubiera 2006-2008) or an 'extended TP domain’ (Fernández Rubiera 2009) as it has no effect on the analysis.

${ }^{21}$ A logical approach to this difference would be to relate it to the existence of declarative contexts in which the verb may raise to a high, C-related position (none in Modern Spanish versus some in Asturian), but I leave this for future research. 